\title{
3 A COMPARISON OF FACTORS IMPACTING ICT GROWTH RATES IN DEVELOPING AND INDUSTRIALIZED COUNTRIES
}

\author{
Kallol Bagchi \\ Peeter Kirs \\ Godwin Udo \\ University of Texas at El Paso \\ EI Paso, TX U.S.A.
}

\begin{abstract}
In this paper we investigate the factors that impact ICT growth rates in developing countries and compare those with factors affecting industrialized countries. Four categories of factors, human development, social structure, institutional factors, and national infrastructure, were considered with respect to their impact on three ICTs: cell phones, PCs, and the Internet. ICT infrastructure influenced ICT growth rates in all nations, but the impacts of human development, institutional index, and urbanization varied between industrialized countries and developing countries.
\end{abstract}

\section{INTRODUCTION}

Information and communication technology (ICT) adoption in industrialized countries (IC) has received extensive attention. Most empirical studies on ICT acceptance have been based in North America using American subjects (Straub 1994). This can be a serious shortcoming, since an important concern in scientific research is external validity, and an international focus is a major component of external validity (Anandarajan et al. 2000). Additionally, many ICT manufacturers of one nation try to expand their business by looking at markets of other nations. Also, policy makers of a nation want to find out the recipe of success in ICT adoption of a nation. Thus nationallevel ICT adoption or growth studies are important. Looking from another angle, Galbraith (1973) considered organizations as information processing systems. Organizations do not exist in a vacuum but have to operate within the frameworks of a

Please use the following format when citing this chapter:

Bagchi, K., Kirs, P., and Udo, G., 2006, in IFIP International Federation for Information Processing, Volume 208, Social Inclusion: Societal and Organizational Implications for Information Systems, eds. Trauth, E., Howcroft, D., Butler, T., Fitzgerald, B., DeGross, J., (Boston: Springer), pp. 37-50. 
national boundary and frequently in the international arena. Thus the study of ICT adoption at a national level becomes all the more significant. A national-level analysis is important (especially in the light of technology transfer and the recent debate on globalization) as this kind of analysis can examine the possible influences of widely varying, country-specific characteristics such as government regulations and institutions, national culture, national economy and infrastructure on ICT adoption.

The body of literature which looks at developing countries (DC) tends to be limited in quantity, scope, and time period of investigation. Most of these studies have either considered a single technology in a single DC (e.g., Cheong (2002) investigated Internet adoption only in Macao), factors influencing ICT adoption in a single DC (e.g., Anandarajan et al. (2000) found that social pressure is an important factor affecting technology acceptance in Nigeria), single or multiple ICT adoptions in a small subset of DCs (e.g., Garcia-Murillo (2003) looked at ICT adoption in Latin America), or considered a single component of technology adoption (e.g., Mbarika et al. (2003) investigated infrastructure growth in DCs). The present study attempts to overcome these shortcomings by considering many factors over a large number of nations and over a period of years.

Our dependent variable of interest is the growth rate at which ICT adoptions have taken place. Growth rate refers to the average yearly change in growth level, in terms of users per 1,000 inhabitants, over some period of time and is an indicator of the speed at which penetration is taking place. While early adoption of technology leads to the establishment of niches in the mass market from which the early adopters can expand and further distance themselves from later adopters (Moore 1991), later adoption offers opportunities to DCs to catch-up at a fraction of the cost which the ICs have invested over many years of ICT evolution (Gerschenkron 1962). The more backward the economy is, the higher the productivity growth rate (within reason). ICs may have passed their peak and slowed down in later years (Barro and Sala-i-Martin 1998). As a consequence, a "leapfrogging" effect (Davidson et al. 2000) implies that DCs will have a greater growth rate than ICs (everything else being equal) by applying an investment-based growth strategy (Acemoglu et al. 2002).

In this paper we follow the Organisation for Economic Co-operation and Development (OECD) classification scheme of nations. Data is available for 34 industrialized countries and 74 developing countries (108 in total).

The complete set of nations used in this paper, by category, is given in Table 1.

The purpose of this study is to investigate the factors that impact ICT growth rates in developing countries and compare those with factors affecting industrialized countries. There are some limitations, however. As a consequence of paucity of data, we have selected only the most important factors based on a literature review to be tested in this study.

\subsection{Dependent Variables}

Since adoption growth rates are affected by the age of the technology, three ICTs (dependent variables) were considered. 
Table 1. Nation Classifications

\begin{tabular}{|l|l|l|l|l|l|}
\hline \multicolumn{1}{|c|}{ Industrialized Countries } & \multicolumn{4}{|c|}{ Developing Countries } \\
\hline Australia & Kuwait & Albania & Czech & Malaysia & Romania \\
Austria & Luxembourg & Algeria & Ecuador & Mali & Russia \\
Bahrain & Malta & Argentina & Egypt & Mauritius & South Africa \\
Belgium & Mexico & Bangladesh & El Salvador & Morocco & Senegal \\
Canada & Netherlands & Barbados & Estonia & Myanmar & Slovenia \\
Cyprus & New Zealand & Belize & Fiji & Namibia & Sri Lanka \\
Denmark & Norway & Benin & Ghana & Nepal & Tanzania \\
Finland & Portugal & Bolivia & Guatemala & Nicaragua & Thailand \\
France & South Korea & Botswana & Guyana & Niger & Togo \\
Gabon & Singapore & Brazil & Honduras & Nigeria & Tunisia \\
Germany & Spain & Bulgaria & India & Oman & Turkey \\
Greece & Sweden & Burundi & Indonesia & Pakistan & United Arab \\
Hong Kong & Switzerland & Cameroon & Jamaica & Panama & Emirates \\
Hungary & United & Chad & Jordan & Paraguay & Uganda \\
Iceland & Kingdom & Chile & Kenya & Peru & Ukraine \\
Ireland & United States & China & Latvia & Philippines & Uruguay \\
Israel & \multicolumn{1}{l|l}{ Colombia } & Lithuania & Papua New & Venezuela \\
Italy & Japan & Costa Rica & Madagascar & Guinea & Zambia \\
\hline
\end{tabular}

- Cell phones. The oldest of the ICTs, the first cell phone call was placed on April 3,1973 , although it must be noted that adoption did not really take off until late in the 1990s in most nations.

- PCs. The MITS Altair was first introduced in January, 1975, and the first viable PCs were the Apple II in 1977 and IBM's PC in 1981, with general acceptance a few years later.

- The Internet. The first Internet website appeared on August 6, 1991.

Sample diffusion growth rates for ICs and DCs are given in Table 2. We limit our examination to four major types of national factors which have been found to impact, or have been suggested as impacting, ICT diffusion growth rates: human development, social structure, institutional factors, and national infrastructure.

\subsection{Independent Variables}

\subsubsection{Human Development}

National wealth, typically measured as gross domestic product (GDP), has long been used as a measure of a country's well-being. While Kraemer et al. (1992) found a direct relationship between the level of development and computing expenditures in 
Table 2. Sample Dependent Variable Data

\begin{tabular}{|l|c|c|c|}
\hline \multirow{2}{*}{} & \multicolumn{3}{|c|}{ Growth Rates } \\
\cline { 2 - 4 } & Cell Phone & PC & Internet \\
\hline Industrialized Countries & & & \\
Sweden & 0.264 & 0.160 & 0.413 \\
Netherlands & 0.510 & 0.143 & 0.342 \\
United States & 0.299 & 0.097 & 0.287 \\
Australia & 0.405 & 0.117 & 0.504 \\
United Kingdom & 0.369 & 0.117 & 0.561 \\
\hline Developing Countries & & & \\
Senegal & 1.865 & 0.190 & 1.829 \\
Benin & 1.076 & 0.218 & 1.727 \\
Tanzania & 1.482 & 0.202 & 1.266 \\
Zambia & 0.853 & 0.049 & 0.771 \\
Nigeria & 0.744 & 0.067 & 0.821 \\
Chile & 0.649 & 0.236 & 0.826 \\
Lithuania & 0.996 & 0.458 & 0.941 \\
India & 0.288 & 0.297 & 0.791 \\
Ghana & 0.550 & 0.438 & 2.009 \\
Bangladesh & 1.275 & 0.694 & 1.854 \\
Nepal & 0.552 & 0.139 & 1.310 \\
Myanmar & 0.592 & 0.663 & 2.583 \\
\hline
\end{tabular}

Notes: Adoption values in 2002 per 1,000 population

Growth Rates of PC, Cell Phone, and Internet from 1990/1995-2002.

the Asia-Pacific region, economic developmental growth theory states that industrial countries differ from developing countries by much more than their level of capital or even their human capital (Hoff and Stiglitz 2000). Development is no longer seen primarily as a process of capital accumulation but rather as a process of organizational change, since industrialized and developing countries are believed to be organized in different ways. Development does not occur just by infusing more capital or by removing government imposed inefficiencies. National development occurs because of the role of institutions and the presence of income inequality, among other things. Stiglitz (2003) proposed that factors such as human capital development, innovation, infrastructure, and level of strategic cooperation between academia, industry, and government are important catalysts for DCs to close the gap with more developed countries.

Investment in human capital involves both education and training. Illiteracy has been suggested as a significant factor hindering the adoption of ICT (Madon 2000). Quibria et al. (2003) have identified education, among other factors, as a key ICT adoption determinant in Asia. Mbarika et al. (2003) cite the acute shortage of ICT technicians as one the factors that inhibits ICT adoption in Sub-Saharan African.

To obtain precise human development (HD) profiles for countries, the United Nations Development Programme (UNDP) industrialized the human development index (HDI) in 1990 (UNDP 1990). The HDI is based on three primary indicators, with each 
indicator given equal weight: longevity (as measured by life expectancy at birth); education attainment (as measured by the combination of adult literacy and combined primary, secondary, and tertiary enrollment ratios), and standard of living (as measured by real gross domestic product).

\subsubsection{Social Structure}

GDP does not necessarily reflect an individual's well-being, since national wealth does not reflect income distribution patterns. Various economic growth studies have pointed out that income inequality is also one of the factors that can also affect the economic growth of a nation (Banerjee and Newman 1998). In global ICT adoption studies, it has been shown that income inequality may play a role in ICT growth. A wide disparity in wealth distribution may mean that some individuals will have enough wealth to buy ICTs to increase their skill levels. Others who do not have enough wealth will not be able to buy ICTs to increase their skill set, thus increasing the differences in ICT adoption levels.

Disparities in wealth can be measured using the GINI Index (Deininger and Squire 1989), which measures the extent to which income among individuals or households within a country deviates from a perfectly equal distribution.

\subsubsection{Institutional Factors}

There are many reasons to expect that free economies will grow more rapidly than those that are less free. The economic freedom of the world (EFW) index contains 38 components designed to measure the degree to which a nation's institutions and policies are consistent with voluntary exchange, protection of property rights, open markets, and minimal regulation of economic activity (Gwartney and Lawson 2003). EFW data provides ratings in five major areas: (1) size of government, (2) legal structure and security of property rights, (3) access to sound money, (4) exchange with foreigners, and (5) regulation of capital, labor, and business.

Because of its international focus, the EFW index has been used extensively to examine cross-country differences in income levels (Grubel 1998), growth rates (Wu and Davis 1999), and other indicators of economic performance (de Vanssay and Spindler 1996). The relationship between the EFW and ICT growth has also been considered. Green et al. (2002) found that freedom alone is important for technological diffusion and, after accounting for the effects of economic freedom, human capital does not affect technological diffusion. With respect to developing countries, Bate and Montgomery (2004) assert that lack of economic freedom is an important factor hindering improved standards of living in developing countries, in part because a lack of economic freedom is also a major obstacle that hinders technology transfer.

The EFW index uses a scale from 0 to 10 , where the country achieving the best results in a given indicator is assigned the value 10 and the country with the worst result receives a 0 ; other countries are assigned values between 0 and 10 for a given indicator. The EFW index provides current ratings for 123 countries and is the only index for which data were available for the entire period of study. 


\subsubsection{National Infrastructure: ICT Infrastructure and Urbanization}

By definition, infrastructure is the underlying base or foundation system, including the basic facilities, services, and installations needed for the functioning of a community or society. A nation's infrastructure includes such components as transportation networks, utilities, commodities distribution networks, and communications networks, and determines how it functions and how flexible it is to meet future requirements. Davis et al. (1989), Toussea-Oulai and Ura (1991), and Mwesige (2003), have all emphasized that poor basic infrastructures are a barrier to ICT adoption in DCs. To properly adopt and use ICTs, basic infrastructure requirements of electricity, trained technical workers, and communication networks, as well as commitment from the government and other policy makers, should be put in place.

Unfortunately, there are no composite measures of national infrastructure. For our purposes, we use ICT infrastructure as a direct measure of existing technical foundation and urbanization as a proxy measure of general infrastructure.

ICT Infrastructure: A modern, reliable, and rapidly expanding telecommunications infrastructure is assumed to contribute to the promotion of a variety of economic expansion activities (World Bank 1991). The level of a country's telecommunications infrastructure has been associated with its teledensity (Saunders et al. 1994), defined as the relationship between a country's population and the number of main telephone lines (International Telecommunications Union 1999). Cronin et al. (1991) found that for the United States, the sum of the output of all industries and the annual GDP were related to the annual amount of U.S. telecommunications investment. In a follow-up study, Cronin et al. (1993) showed that investment in telecommunications infrastructure (represented by teledensity) was a reliable predictor of national productivity. Ein-Dor et al. (1997) found that small developed countries may have an advantage over larger developed nations if they have a well developed infrastructure and the human skills needed. Dewan and Kraemer (2002) found that the returns from IT capital investments are positive and statistically significant for developed countries, but nonsignificant for developing countries.

Accordingly, our ICT infrastructure measure is the number of mainline telephone installations per 1,000 in a nation.

Urbanization: In 1880 , only 3 percent of the world's population lived in urban areas while by 1950 , it was 29 percent, and shortly after the year 2000 , it was greater than 50 percent of the world's population. United Nations projections are that 80 percent of the growth in population over the coming decade will be urban, not rural (Perlman 1993). It is generally acknowledged that urban areas play a vital role in education, culture, and productivity. Consumers living in a country's major metropolitan areas tend to be more cosmopolitan (Hannerz 1990), and diffusion research has documented a positive relationship between cosmopolitanism and the tendency to innovate (Gatignon et al. 1989). Metropolises also tend to have a denser retail infrastructure, thus making it easier for consumers to acquire a new product. Regions with dense concentrations of firms engaged in the same production process are also likely to be information-rich (Marshall 1920).

With respect to DCs, Loboda (1974) has shown that the diffusion of televisions in Poland predominately took place in the richest and the most urban parts of the country. 
Proenza (2001)notes that the use of ICTs has grown rapidly only in the most urban areas in Africa. Shakeel et al. (2001) found that telecenters, locations which facilitate and encourage a wide variety of public and private information-based goods and services, are primarily found in urban areas.

\section{THE RESEARCH MODEL AND HYPOTHESES}

The general research model consists of five independent variables and three dependent variables, each analyzed independently for each set of nation groupings (see Figure 1). In accordance with the tenets that ICs may have passed their peak and slowed down in later years (Mahajan and Peterson 1985) and that DCs are experiencing a leapfrogging effect (Davidson et al. 2000), we expect that ICT growth rates will be negatively impacted by all of the independent variables, with the exception of social structure, which is measured using an inverse scale.

\section{DATA AND METHODS}

While the basic focus of this research is on developing countries, we first ran regressions using all countries (ACs), providing us with baseline indicators, and then, in order to provide a contrast, industrialized and developing countries were compared. Nine ordinary least squares (OLS) regressions were conducted, three for each ICT growth rate technology for each of the three groups of countries (AC, IC, DC). The regressions were checked for possible multicollinearity, autocorrelations, etc. (Netter et al. 1996).

Typically, diffusion growth modeling studies try to explain patterns of diffusion of technology, usually over time and across a population of potential adopters. Observations of adoption or percentages of adoption are put in the form of a time series and fitted to some functional form (Fichman 1992; Mahajan and Peterson 1985). The functional form of the logistic model used to calculate the growth rate is given by

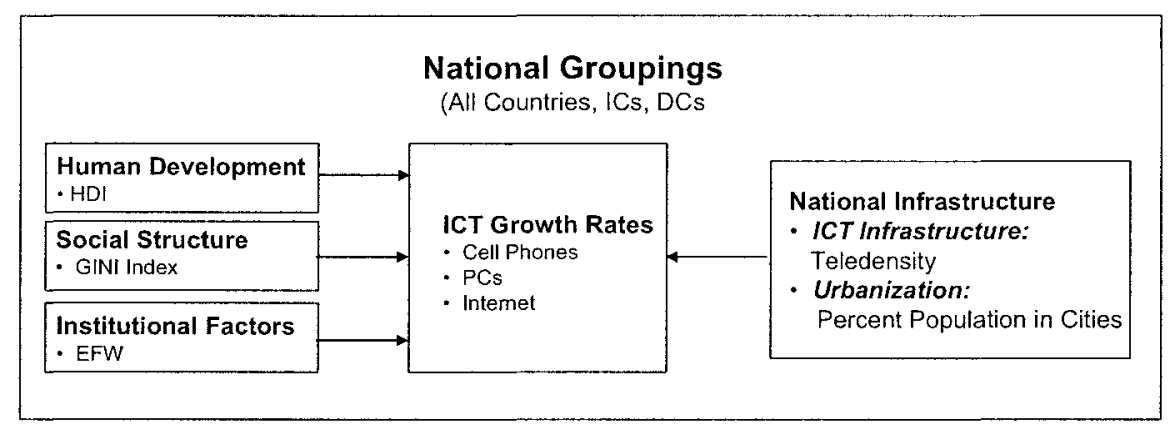

Figure 1. The General Research Model 


$$
Y=1 /\left(1 / u+\left(b_{0}^{*} b_{l}^{t}\right)\right)
$$

Where: $u$ is the upper boundary value and $b_{0}$ and $b_{1}$ are parameters to be estimated

We specify the upper boundary value as 1000 in the regression equation. It can be mentioned that the logistic model is a standard and popular one which has been used in many previous growth studies (Mahajan and Peterson 1985). The maximum penetration rate is achieved at $.50 \mathrm{u}$, where $u$ is the limit of penetration. The model is symmetric in nature.

Each of the dependent and independent variables used in the regressions are described in Table 3 . As mentioned above, our data are secondary in nature and are collected from various reliable databases. Combining data from more than one source may create problems. However, this method has been used in traditional macro economic and marketing literature research studies (Dekimpe et al. 1994; Gatignon et al. 1989).

Table 3. Summary of Variables, Sources and Representation

\begin{tabular}{|c|c|c|c|c|}
\hline Variables & Source & Representation & Years & Factor \\
\hline \multicolumn{5}{|l|}{ Dependent Variables } \\
\hline $\begin{array}{l}\text { Average ICT } \\
\text { Adoption Level* }\end{array}$ & \begin{tabular}{|l|}
$\begin{array}{l}\text { World } \\
\text { Bank }\end{array}$ \\
\end{tabular} & $\begin{array}{l}\text { Adoption Level per } \\
\text { 1,000 Residents }\end{array}$ & See Below** & $\begin{array}{l}\text { Adoption } \\
\text { Level } \\
\end{array}$ \\
\hline ICT Adoption Rate* & \begin{tabular}{|l} 
Calculated \\
(see below)
\end{tabular} & $\begin{array}{l}\text { ICT Diffusion over } \\
\text { time }\end{array}$ & See Below** & Growth rate \\
\hline \multicolumn{5}{|c|}{ Independent Variables } \\
\hline $\begin{array}{l}\text { Average Human } \\
\text { Development Index } \\
\text { (HDI) }\end{array}$ & UNDP & $\begin{array}{l}\text { National Human } \\
\text { Development }\end{array}$ & $\begin{array}{l}\text { Average of } \\
1990 / 1995 \text { and } \\
2002\end{array}$ & $\begin{array}{l}\text { Human } \\
\text { Development }\end{array}$ \\
\hline $\begin{array}{l}\text { Average Economic } \\
\text { Free World (EFW) } \\
\text { Index }\end{array}$ & $\begin{array}{l}\text { Fraser } \\
\text { Institute }\end{array}$ & $\begin{array}{l}\text { National growth in } \\
\text { free economies }\end{array}$ & $\begin{array}{l}\text { Average of } \\
1990 / 1995 \text { and } \\
2002\end{array}$ & $\begin{array}{l}\text { Institutional } \\
\text { Factors }\end{array}$ \\
\hline $\begin{array}{l}\text { National Distribution } \\
\text { of Wealth (GINI) }\end{array}$ & $\begin{array}{l}\text { World } \\
\text { Bank } \\
\end{array}$ & GINI Index & \begin{tabular}{|l|} 
Average of \\
1980 and 2002 \\
\end{tabular} & $\begin{array}{l}\text { Social } \\
\text { Structure } \\
\end{array}$ \\
\hline $\begin{array}{l}\text { Average ICT } \\
\text { Infrastructure } \\
\text { (ITINFRA) } \\
\end{array}$ & $\begin{array}{l}\text { World } \\
\text { Bank }\end{array}$ & $\begin{array}{l}\text { Telephone Mainlines } \\
\text { per 1,000 Residents }\end{array}$ & $\begin{array}{l}\text { Average of } \\
1990 / 1995 \text { and } \\
2002 \\
\end{array}$ & $\begin{array}{l}\text { ICT } \\
\text { Infrastructure }\end{array}$ \\
\hline $\begin{array}{l}\text { Average } \\
\text { Urbanization (URB) }\end{array}$ & $\begin{array}{l}\text { World } \\
\text { Bank }\end{array}$ & $\begin{array}{l}\% \text { National Urban } \\
\text { Population }\end{array}$ & $\begin{array}{l}\text { Average of } \\
1990 / 1995 \text { and } \\
2002\end{array}$ & $\begin{array}{l}\text { National } \\
\text { Infrastructure }\end{array}$ \\
\hline
\end{tabular}

* For each of the ICTs considered: cell phones, PCs, and Internet

** Average cell phone levels and rates are based on the average of 1990 and 2002

Average PC levels and rates and rates are based on the average of 1990 and 2002

Average Internet levels and rates and rates are based on the average of 1995 and 2002 
Table 4. Growth Rate Regression (Beta Values) Results

\begin{tabular}{|c|c|c|c|}
\hline Technology & $\begin{array}{c}\text { All } \\
\text { Nations (AC) }\end{array}$ & $\begin{array}{c}\text { Industrialized } \\
\text { Nations (IC) }\end{array}$ & $\begin{array}{c}\text { Developing } \\
\text { Nations (DC) }\end{array}$ \\
\hline \multicolumn{4}{|l|}{ Cell } \\
\hline HDI & -0.14 & $0.86^{*}$ & $-0.59^{*}$ \\
\hline ICT Infrastructure & 0.25 & -0.68 & $0.89 * * *$ \\
\hline Urbanization & -0.25 & $-0.45^{*}$ & -0.21 \\
\hline EFW Index & $-0.40^{*}$ & -0.35 & $-0.26^{*}$ \\
\hline GINI Index & $0.23 *$ & 0.16 & $0.30^{*}$ \\
\hline $\operatorname{Adj~} R^{2}$ & 0.28 & 0.35 & 0.30 \\
\hline $\mathbf{N}$ & 69 & 21 & 48 \\
\hline \multicolumn{4}{|l|}{$P C$} \\
\hline $\mathrm{HDI}$ & $0.89^{* * *}$ & $-1.24 * * *$ & $0.90^{* * *}$ \\
\hline ICT Infrastructure & $-0.97 * * *$ & 0.16 & 0.10 \\
\hline Urbanization & $-0.48 * * *$ & $-0.17^{*}$ & $-0.86 * * *$ \\
\hline EFW Index & 0.11 & $0.27^{*}$ & 0.05 \\
\hline GINI Index & -0.01 & -0.17 & 0.07 \\
\hline Adj $R^{2}$ & 0.32 & 0.76 & 0.31 \\
\hline $\mathbf{N}$ & 69 & 27 & 41 \\
\hline \multicolumn{4}{|l|}{ Internet } \\
\hline HDI & -0.27 & -0.02 & $-0.05^{*}$ \\
\hline ICT Infrastructure & $-0.54 * * *$ & -0.31 & -0.55 \\
\hline Urbanization & -0.08 & $0.26^{* *}$ & -0.14 \\
\hline EFW Index & 0.01 & $-0.60^{* * *}$ & -0.02 \\
\hline GINI Index & -0.06 & 0.16 & -0.10 \\
\hline Adj $R^{2}$ & 0.62 & 0.68 & 0.40 \\
\hline $\mathbf{N}$ & 83 & 28 & 54 \\
\hline
\end{tabular}

\section{RESULTS}

Table 4 presents the results of regressions on ICT diffusion growth rates for each of the three ICTs considered, using the five dependent variables for each of the groupings of countries.

The predictive power of the growth rate model varied across technologies. For $\mathrm{ACs}$, the adjusted $\mathrm{R}^{2}$ ranged between 0.28 (cell phones) to 0.62 (Internet). For each of the other national groupings, the adjusted $R^{2}$ values ranged between 0.30 (cell phone growth rates in DCs) to 0.76 (PC growth rates in $\mathrm{ICs}$ ). No single factor was significant across all groupings, although ICT infrastructure was significant for two of the three groups for Internet growth rate. Human development (HDI), EFW, and income inequality (GINI) indices were significant for two of the three groups for cell phone growth, although again not always in the direction hypothesized. 
Table 5. Significant Factors/Combinations of Factors Affecting Growth Rates

\begin{tabular}{|l|c|c|c|}
\hline \multicolumn{1}{|c|}{ Factors } & All (AC) & IC & DC \\
\hline Cell Phone & & $\mathrm{X}$ & $\mathrm{X}$ \\
\hline HDI & & & $\mathrm{X}$ \\
\hline ICT Infrastructure & & $\mathrm{X}$ & \\
\hline Urbanization & $\mathrm{X}$ & & $\mathrm{X}$ \\
\hline EFW Index & $\mathrm{X}$ & & $\mathrm{X}$ \\
\hline GINI Index & $\mathrm{X}$ & $\mathrm{X}$ & $\mathrm{X}$ \\
\hline PC & $\mathrm{X}$ & & \\
\hline HDI & $\mathrm{X}$ & $\mathrm{X}$ & $\mathrm{X}$ \\
\hline ICT Infrastructure & \multicolumn{3}{|l|}{} \\
\hline Urbanization & $\mathrm{X}$ & $\mathrm{X}$ & \\
\hline EFW & \multicolumn{1}{|l|}{} \\
\hline Internet & $\mathrm{X}$ & $\mathrm{X}$ \\
\hline ICT Infrastructure & & \\
\hline Urbanization & EFW Index
\end{tabular}

With respect to the PC growth rate, HDI (three of three cases), ICT infrastructure (one out of three cases), and urbanization (three out of three cases) were significant for all groupings. Institutional factors were mostly significant for industrialized countries, but not for developing countries in general. Internet growth rate was most impacted by ICT infrastructure, except for ICs (largest value of betas). IC Internet growth rate was impacted by urbanization and institutional factors. For the cell phone rate model, HDI, ICT infrastructures, income inequality index (GINI index), and institutional factor (EFW index) became significant in the DC regression. Table 5 summaries the significant results for the growth rate analysis.

The results in terms of growth rate factors are discussed next. With respect to the growth rate of ICTs in general, ICT infrastructure tends to be one of the most significant factors for all nations and DCs in general and not for ICs. It was significant for both cell phones and Internet growth rates for all DCs. It was not significant for PC growth in DCs. Institutional factors also had a high impact on growth rates. For ACs, its significant impact on cell phone growth rates was noteworthy.

Human development was an important factor on growth rate, especially with respect to cell phones and PCs. The relationship between cell phone rates and the HDI index is positive for ICs and the relationship between cell phone rates and the HDI is negative for DCs. The relationship is just the opposite in case of PC growth rate and ICs/DCs. The cell phone is a new technology and so wealthier nations are still adopting it in large numbers. For developing nations, leapfrogging is taking place. Poorer nations are skipping the traditional adoption path of first telephones and then cell phones. This is possible also because of comparative low costs of installing cell phones in developing nations. The $\mathrm{PC}$ is an older technology and relative to cell phones, $\mathrm{PCs}$ are more 
expensive and require more education to operate (two major components of the HDI). Among ICs, richer nations may have reached a peak in $\mathrm{PC}$ adoption and so the relation is reverse. In DCs, because of costs and education involved, PCs are getting adopted in comparatively educated and richer nations. HDI was not a factor in Internet growth rate, perhaps because Internet growth rate does not depend on GDP or education and can flourish in less affluent countries.

The GINI index of income inequality was not significant for any nation cluster as far as Internet and PC growth rates were concerned. Urbanization did impact growth rate, especially in ICs. This finding offers some support for Gatignon et al.'s (1989) assertions of the relationship between cosmopolitanism and the tendency to innovate, and Marshall's (1920) finding that regions with dense concentrations of firms engaged in the same production process are likely to be information-rich since, for the most part, urbanization is more pronounced in ICs.

\section{CONCLUSIONS}

Technologies were initially developed in wealthier countries and then percolated down to developing countries (Walsham 2001). The present study examined the antecedents of ICT growth rate. It was motivated by the need to extract the rate factors that technologies seem to have in common for DCs and ICs and provide us with an overall picture. Our study indicates that factors impacting growth rates differ for DCs and ICs.

The study results show that traditional growth theory can not adequately explain the phenomena of ICT growth in developing countries. This conforms to developmental theories which posit that developmental and gender-related variables, institutional and cultural factors can all play a role in ICT developments in DCs (Walsham 2001). Managers and policy makers should be aware that if technology transfers are to be encouraged, developmental and institutional changes need to be promoted accordingly.

The study offers many contributions. First, the study contributes to the IS developmental research by identifying factors that are responsible for ICT diffusion in ICs and DCs. Previous studies are lacking in this respect. Too often, few countries are grouped together and attempts are made to generalize the conclusions. Specifically, our contribution lies in (1) identifying a set of indicators for ICT growth, (2) including as many countries as possible in the study, subject to the data availability (our major constraint) to generalize the results, and (3) observing that ACs, ICs and DCs have a similar yet distinct set of influencing factors for ICT diffusion rates.

This study has some limitations. Many researchers have previously noted the problems of cross-country research (Barro and Sala-i-Martin,1998; Gibbs 1995). Data sets are often incomplete, data availability is limited, and data can contain errors. This problem was summarized by Gibbs (1995) when he noted that the problem with research on developing countries is not in the laboratory, but in the library. This problem is exacerbated when attempting to conduct longitudinal studies on DCs. Whereas recent data are generally available, it is difficult to find data from 10 years earlier. For example, by 2001 (and after), HDI data was available for 177 countries. In 1995, data was available for only 145 countries, and in 1985 HDI data was available for only 120 countries. Combining incomplete data for various variables further reduces the data set to a common denominator set. 
Future research should investigate additional factors, such as culture and trust, all of which have been shown to affect some ICT adoptions in previous studies (Bagchi et al 2004; Boudreau et al. 1998; Walsham 2001; Walsham and Sahay 1999). Our continuing research efforts are in these directions.

\section{References}

Acemoglu, D., Aghion, P., and Zilibotti, F. "Distance to Frontier, Selection, and Economic Growth,"NBER Working Paper 9066, National Bureau of Economic Research, Cambridge, MA, 2002.

Anandarajan, M., Igbaria, M., and Anakwe, U. P. "IT Acceptance in a Less-Industrialized Country: A Motivational Factor Perspective," International Journal of Information Management (22:1), 2000, pp. 47-65.

Bagchi, K., Hart, P., and Peterson, M. IT Product Adoption and the Influence of National Culture," Journal of Global Information Technology Management (7:4), Special Issue on Cross-Cultural IS Research, October 2004, pp. 29-46.

Banerjee, A. V., and Newman, A. F. "Information, the Dual Economy, and Development," Review of Economic Studies (65), October 1998, pp. 631-653.

Barro, R., and Sala-1-Martin, X. Economic Growth, Cambridge, MA: MIT Press, 1998.

Bate, R., and Montgomery, D. "Beyond Kyoto: Real Solutions to Greenhouse Emissions from Developing Countries," Environmental Policy Outlook, July-August 2004, pp. 1-13 (available online at http://www.aei.org/publications/pubID.20982/pub_detail.asp).

Boudreau, M.-C., Loch, K. D., Robey, D., and Straub, D. "Going Global: Using Information Technology to Advance the Competitiveness of the Virtual Transnational Organization," The Academy of Management Executive (12:4), 1998, pp. 120-128.

Cheong, W. H. "Internet Adoption in Macao," Journal Computer-Mediated Communication (7:2), 2002 (available online at http://jcmc.indiana.edu/vol7/issue2/macao.html).

Cronin, F. J., Colleran, E. K., Herber, P. L., and Lewitzky S. "Telecommunications and Growth: The Contribution of Telecommunications Infrastructure Investment to Aggregate and Sectoral Productivity," Telecommunications Policy (17:9), 1993, pp. 677-690.

Cronin, F. J., Parker, E. B., Colleran, E. K., and Gold, M. A. "Telecommunications Infrastructure and Economic Growth: An Analysis of Causality," Telecommunications Policy (15:6), 1991, pp. 529-535.

Davidson, R., Vogel, D., Harris, R., and Jones, N. "Technology Leapfrogging in Developing Countries: An Inevitable Luxury," Electronic Journal on Information Systems in Developing Countries (1:5), 2000, pp. 1-10 (available online at http://www.is.cityu.edu.hk/ research/ejisdc/vol1/v1d5.pdf).

Davis, F. D., Bagozzi, R., and Warshaw, P. R. "User Acceptance of Computer Technology: A Comparison of Two Theoretical Models," Management Science (35:8), 1989, pp. 982-1003.

Deininger, K., and Squire, L. "Economic Growth and Income Inequality: Reexamining the Links," Finance and Development (34:1), March 1997, pp. 38-41.

Dekimpe, M. G., Parker, P. M., and Sarvary, M. "Modeling Global Diffusion," Working Paper 94/72/MKT 31, INSEAD, Fontainebleau, France, 1994.

Dewan, S., and Kraemer, K. K. "Information Technology and Productivity: Evidence from Country-Level Data," Management Science (46:4), 2000, pp. 548-562.

de Vanssay, X., and Spindler, Z. A. "Constitutions, Institutions and Economic Convergence: An International Comparison," Joumal for Studies in Economics and Econometrics (20:3), 1996, pp. 1-19.

Ein-Dor, P., Myers, M. D., and Raman, K. S. "Information Technology in Three Small Developed Countries," Journal of Management Information Systems (13:4), 1997, pp. 61-89. 
Fichman, R. G. "Information Technology Diffusion: A Review of Empirical Research," in J. I. DeGross, J. D. Becker, and J. J. Elam (eds.), Proceedings of the $13^{\text {th }}$ International Conference on Information Systems, Dallas, TX, 1992, pp. 195-206.

Galbraith, J. R. Designing Complex Organizations, Reading, MA: Addison-Wesley, 1973.

Garcia-Murillo, M. "Patchwork Adoption of ICTs in Latin America," The Electronic Journal on Information Systems in Developing Countries (15:1), 2003, pp. 1-9.

Gatignon, H., Eliashberg, J., and Robertson, T. S. "Modeling Multinational Diffusion Patterns: An Efficient Methodology," Marketing Science (8:3), 1989, pp. 231-247.

Gerschenkron, A. Economic Backwardness in Historical Perspective, Cambridge, MA: Belknap Press, 1962.

Gibbs, W. W. "Lost Science in the Third World," Scientific American, August 1995, pp. 92-99.

Green, S., Melnyk, A., and Powers, D. "Is Economic Freedom Necessary for Technology Diffusion?," Applied Economics Letters (9:14), 2002, pp. 907-910.

Grubel, H. G. "Economic Freedom and Human Welfare: Some Empirical Findings," Cato Journal (18:2), 1998, pp. 287-304.

Gwartney, J., and Lawson, R. "Economic Freedom of the World: 2003 Annual Report," The Fraser Institute, Vancouver, 2003.

Hannerz, U. "Cosmopolitans and Locals in World Culture," Theory, Culture \& Society (7:2/3), 1990, pp. 237-251.

Hoff, K., and Stiglitz, J. E. "Modern Economic Theory and Development," in G. Meier and J. Stiglitz (eds.), Frontiers of Development Economics: The Future in Perspective, Oxford, England: Oxford University Press, 2000, pp. 389-459.

Hofstede, G. Cultures and Organizations: Software of the Mind: Intercultural Cooperation and its Importance for Survival, Cambridge, England: McGraw-Hill, 1991.

International Telecommunications Union (ITU). Telecommunications Indicators Handbook, Geneva: ITU, 1999.

Kraemer, K. L., Gurbaxani, V., and King, J. L. "Economic Development, Government Policy, and the Diffusion of Computing in Asia-Pacific Countries," Public Administration Review (52:2), 1992, pp. 146-156.

Loboda, J. "The Diffusion of Television in Poland," Economic Geography (50:1), 1974, pp.70-82.

Mbarika, V. W., Kah, M. M. O., Musa, P. F., Meso, P., and Warren, J. "Predictors of Growth of Teledensity in Developing Countries: A Focus on Middle and Low-Income Countries," The Electronic Journal on Information Systems in Developing Countries (12:1), 2003, pp. $1-16$.

Madon, S. "The Internet and Socio-Economic Development: Exploring the Interaction," Information technology and People (13:2), 2000, pp. 85-101.

Mahajan, V., and Peterson, R. Models for Innovation Diffusion ( $2^{\text {nd }}$ ed.), Beverly Hills, CA: Sage Publications, 1985.

Marshall, A. Principles of Economics ( $8^{\text {th }}$ ed.), London: MacMillan, 1920.

Moore, G. A. Crossing the Chasm: Marketing and Selling High-Tech Goods to Mainstream Customers, New York: HarperBusiness, 1991.

Mwesige, P. G. "Cyber Elites: A Survey of Internet Cafe Users in Uganda," Telematcs \& Informatics (21), 2003, pp. 83-101.

Neter, J., Kutner, M., Nachtsheim, C., and Wasserman, W. Applied Linear Statistical Models, Chicago: Irwin Press, 1996.

Perlman, J. E. "Global Urbanization: Challenges and Opportunities," Publication MCP-013, The Mega-Cities Project, 1993 (http://www.megacitiesproject.org). 
Proenza, F. J. "Telecenter Sustainability: Myths and Opportunities," The Journal of Development Communication (12:2), 2001, pp. 94-109.

Quibria, M. G., Ahmed, S. N., Tschang, T., and Reyes-Macasaquit, M. "Digital Divide: Determinants and Policies with Special Reference to Asia," Journal of Asian Economics (13), 2003, pp. 811-825.

Saunders, R. J., Warford, J. I., and Wellenius, B. Telecommunications and Economic Development ( ${ }^{\text {nd }}$ ed.), Baltimore, MD: John Hopkins University Press, 1994.

Shakeel, H., Best, M., Miller, B., and Weber, S. "Comparing Urban and Rural Telecenters Costs," The Electronic Journal on Information Systems in Developing Countries (4:2), 2001, pp. $1-13$.

Straub, D. W. "The Effect of Culture on IT Diffusion: E-mail and Fax in Japan and the US," Information Systems Research (5), 1994, pp. 23-47.

Stiglitz, J. "Globalization and Growth in Emerging Markets and the New Economy," Journal of Policy Modeling (25), 2003, pp. 505-524.

Toussea-Oulai, A., and Ura, S. "Information Technology Transfer: Problems Facing African Developing Nations," International Journal of Human-Computer Interaction (3:1), 1991, pp. 79-93.

UNDP. "World Development Report 1990," United Nations Development Programme, Oxford, England, 1990.

Walsham, G. Making a World of Difference: IT in a Global Context, Chichester, England: Wiley, 2001.

World Bank. World Bank Telecommunications Sector Reports, Washington, DC, 1991.

World Bank. "Country Classifications," 2005 (available online at http://www.worldbank.org/ data/countryclass/classgroups.htm).

Wu, W., and Davis, O. A. "The Two Freedoms, Economic Growth and Development: An Empirical Study," Public Choice (100), 1999, pp. 39-64.

\section{About the Authors}

Kallol Bagchi is an assistant professor in the Department of Information and Decision Sciences in the College of Business at the University of Texas at El Paso. He can be reached at kbagchi@utep.edu.

Peeter Kirs is an associate professor in the Department of Information and Decision Sciences in the College of Business at the University of Texas at El Paso. He can be reached at pkirs@utep.edu.

Godwin Udo is a full professor in the Department of Information and Decision Sciences in the College of Business at the University of Texas at El Paso. He can be reached at gudo@utep.edu. 